\title{
Effect of freeze-drying and production process on the chemical composition and fatty acids profile of avocado pulp
}

\author{
Efecto del liofilizado y del proceso de \\ producción en la composición química y el \\ perfil de ácidos grasos de la pulpa de aguacate
}

\begin{abstract}
Freeze-drying technology is the best dehydration process to preserve shelf-life and allowing avocado to maintain its sensorial and nutritional characteristics. The aim of this work was to determine if the freeze-drying and production condition have an effect on the nutritional quality of the avocado pulp grown in rain-fed and irrigation orchards. Four treatments were applied: non-freezedried rain-fed fruits, non-freeze-dried irrigation fruits, freeze-dried rain-fed fruits and freeze-dried irrigation fruits. Results showed that the fruit is made up of $71.4 \%, 16 \%$, and $12.6 \%$ pulp, seed and skin, respectively. The pulp is made up of $71.51 \%, 19.96 \%$, $2.81 \%, 0.51 \%$ and $1.51 \%$ water, lipids, ashes, crude fiber and protein, respectively. Avocado oil is composed by $61 \%, 18.8 \%$, $11.6 \%$ and $7 \%$ oleic, palmitic, linoleic, and palmitoleic fatty acids, respectively. The freeze-drying decreased the linoleic acid by $1.43 \mathrm{~g} / 100 \mathrm{~g}$. Under rain-fed conditions $4 \%$ and $13 \%$ less total fat and oleic fatty acid are produced than in irrigation conditions. We conclude that freeze-dried avocado pulp shows slight changes in their nutritional quality.

Key words: fatty acids; freeze-drying; irrigation; rain fed, avocado.
\end{abstract}

\section{INTRODUCTION}

The avocado (Persea Americana) is native to America. The domestication was performed in Middle America and perhaps due to the commercial exchange between native civilizations, the avocado was distributed and adapted to Central America, spreading to Colombia, Venezuela, Ecuador and Perú (1). Avocado farming thrives in different ecological conditions of the world. Mexico is considered the first producer and exporter of avocado worldwide with a cultivated surface of 141,408 ha, of which 108,678 are grown in Michoacán, which represent $76 \%$ of the national surface with a production of 1,092,322 t (2). In 2012, avocado exports reached 31,666,356 dollars (3). Although Michoacán is Mexico's main producer, there are other states like Jalisco that are gaining importance on a national level due to the increase in the surface showed with
Ma Claudia Castañeda-Saucedo (1) Elia Herminia Valdés-Miramontes (2) Ernesto Tapia-Campos (3)

Adriana Delgado-Alvarado (4) Ana Cecilia Bernardino-García (2) María Rosario Rodríguez-Ramírez (5) Jessica del Pilar Ramirez-Anaya (2)

(1) Laboratorio de fisiología Vegetal, Departamento de Sociedad y Economía. México. (2) Laboratorio de Análisis Físico-químicos de Alimentos, Departamento de Desarrollo Regional, Centro Universitario del Sur (CUSUR). México. (3) Unidad de Biotecnología Vegetal, Centro de Investigación y Asistencia en Tecnología y Diseño del Estado de. Jalisco A. C. (CIATEJ), México. (4) Área Restringida de la Unidad de Laboratorios del Colegio de Postgraduados, Campus Puebla, México.

(5) Laboratorio de Bromatología del Instituto Nacional de Investigaciones Forestales y Agropecuarias (NIFAP). Campus, Tecomán, Colima, México.

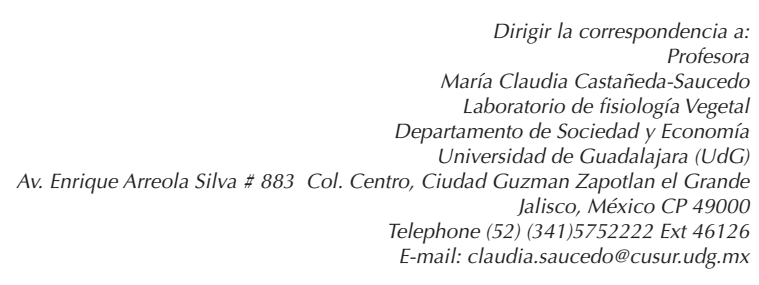

Este trabajo fue recibido el 28 de Marzo de 2014 y aceptado para ser publicado el 8 de septiembre de 2014.

avocado. According to the SAGARPA 2011 (4), in Jalisco there are 10,000 ha of avocado (60\% in production and $40 \%$ in growing). Currently, the global economic environment favors the exchange of food products among countries, with a tendency towards natural food production with the least amount of chemical products for its production and preservation. Good avocado pulp must contain between $98 \%$ and $99 \%$ pulp and only between 2 and $1 \%$ of additives (5). This is why the need to present new alternatives of food processing emerges, which include insofar as possible, only physical processes for its preservation (6). Water removal is a form of preserving food that has been used for hundreds of years $(7,8)$. The combined methods of dehydration are preservation techniques that can be considered for the minimum processing of food (8). These methods focus on the use of technologies that leads towards 
to preserving food where the smell and taste characteristics of the original products are maintained (8-10). The freeze-drying technology is a dehydration process at a sufficiently low temperature, modifying the pressure, and is emerging as an alternative of food preservation, as it is a process based on the separation of water by sublimation $(8,11,9)$. It is a drying method that allows obtaining products with the same typical characteristics of the freeze-drying material, which has been used in a great range of heat-sensitive products that require high quality standards (9).

The freeze-drying product does not change form, is easily rehydratable $(8,11,12)$ and can prevent the growth of microorganisms $(6,8,11)$. Freeze-drying is undoubtedly the best option for dehydrating avocado $(13,9)$. It is presented as a value-added alternative of the fruit (14), displaying other benefits that the fresh fruit does not, such as longer shelf life, lower weight to transport to other markets with greater distance from the production point $(7,13)$; although the high costs of freeze-drying restrict its application on a large scale in the food industry (9).

In foods such as cocoa (Theobroma cacao L.) has been proved that the drying process often significantly affects aroma and flavor compounds (15); however, freeze-drying can maximize the conservation of these taste compounds compared with other techniques such as natural air drying, vacuum and microwave in mushroom (Pleurotus eryngii) (16), also freeze drying holds more nonvolatile flavor compounds that freeze drying combined with microwave vacuum drying in button mushroom (Agaricus biosporus) (17).

Little is known within the current literature about the composition of freeze-drying avocado pulp, but some effects derived from this drying technology had been mentioned on the composition of other fruits. Some examples are freeze-drying blueberries (Vaccinium corymbosum) and strawberries (Fragaria $X$ Ananassa), there were found increments in the content of trace $(\mathrm{Cu}, \mathrm{Fe}, \mathrm{Mn}$ and $\mathrm{Zn})$, minor $(\mathrm{B}, \mathrm{Na}, \mathrm{Mg}, \mathrm{P}, \mathrm{K}, \mathrm{Ca}, \mathrm{Ni}, \mathrm{Ge}$, $\mathrm{Se})$, and toxic trace elements ( $\mathrm{Al}, \mathrm{As}, \mathrm{Cd}$ and $\mathrm{Pb})$, as a result of the reduction of water levels existed in the product (18).

In ginger (Alpinia zerumbet, Etlingera elatior, Curcuma longa and Kaempferia galangal) and some flowers from the genus Cytisus, the low processing temperatures during freeze-drying exerts a protecting effect on termolabile compounds like phenolics, sugars, tocopherols, chlorophylls and lycopene as well as the antioxidant activity $(19,20)$. In whole-lemon (Citrus limon, L.) powder, García-Salas et al., (2013) reported a detrimental effect on the content of phenolic compounds, and the concentration of organic acids as citric acid and its isomers; besides, prevents the formation of furanic compounds associated to non enzymatic browning as a result of the limited triggering of the Maillard reaction (21). In kiwifruit non browning was reported in freeze-drying pulp (22). Also, volatile constituents present in essential oils as terpenes in bakhtiari savoy (Satureja bachtiarica Bunge) (23) and basil (Ocimun basilicum) (24) are better retained, and no significant differences occurred among several constituents in the extracted essential oils as compared with a fresh sample.

A potential issue with freeze-drying and grinding samples containing polyunsaturated fatty acids (PUFA) and especially long chain (LC; C20*) PUFA, is its susceptibility to oxidation. This susceptibility is associated with the storage of the sample and not by the drying process per se, as it has been acknowledged that freeze-drying of samples is the safest drying method to preserve the fatty profile in microencapsulated walnut oil (25). In other drying methods, like dried by atomization, the peroxide index increases at the beginning of the storage, the lipids decreases during the storage, both in refrigeration and at room temperature. This decrease could be due to the oxidation of the product suffering the heat treatment fatty acids used (26). There are papers on freeze-drying avocado, but none were found that considered the freeze-drying effect on the nutritional quality of the avocado pulp, specifically of the fatty acids, as the fat represents the main component after the fruit's moisture. Thus the aim of this research was to determine if the freeze-drying and production condition have an effect on the fatty acids profile and the nutritional quality of the avocado pulp in rainfed and irrigation orchards.

\section{MATERIAL AND METHODS}

Avocado fruits of the variety "Hass" from an irrigation orchard and a rainfed orchard, both 30 years old, located in the South of Jalisco, Mexico were collected. Ten trees in each orchard were randomly selected, from which three samples of $3 \mathrm{~kg}$ ( $9 \mathrm{~kg}$ in total) or fruits physiological maturity. Three replicates of $1 \mathrm{~kg}$ were placed in each orchard, which were peeled and sliced. $500 \mathrm{~g}$ were freeze-drying, and 500 were non-freeze-drying for chemical analysis and fatty acids. The treatments established were: 1) fruits in rainfed conditions and non-freeze-drying (RC+NFD), 2) fruits in rainfed conditions and freeze-drying ( $R C+F D), 3)$ fruits in irrigation conditions and non-freeze-drying (IC+NFD), and 4) fruits in irrigation conditions and freeze-drying (IC+FD). Avocado orchards grown under rainfed conditions (RC) had a total rainfall of $842.5 \mathrm{~mm}$, while avocado orchards grown under irrigation conditions had a total rainfall of $842.5 \mathrm{ml}$ plus $200 \mathrm{~L}$ per tree per week during dry periods. This study used a $2 \times 2$ factorial design with three replicates; one factor was the production system (irrigation or rainfed) and the other one was freeze-drying (freeze-drying and non-freeze-drying pulp). Therefore four treatments were analyzed, the variables assessed were: total fat, protein, ashes, fiber, palmitic, palmitoleico, oleic and linoleic acids. Data were analyzed through an analysis of variance followed by Tukey's test $(\mathrm{P}<0.05)$ using the program SAS (Statistical Analysis System) for Windows $\vee 9.0$ (27).

\section{Parts of fruit avocado}

The weight in pulp (mesocarp), seed and skin (exocarp) in each of the fruits collected was determined.

\section{Freeze-drying avocado pulp}

$500 \mathrm{~g}$ of pulp (mesocarp) cut lengthways of one $\mathrm{cm}$ of wide in special freeze-drying bottles were placed. They were frozen at $-40^{\circ} \mathrm{C}$ during one hour. Immediately afterwards they were freeze-drying during 72 hours at a temperature of -40 ${ }^{\circ} \mathrm{C}$ in an ultra-freezer).The Freeze Dry System/Lyph Lock $4.5 \mathrm{~L}$ (77510-00) was used with a pressure of $1,33 \times 10^{-3}$ mbar. Once the pulp was freeze-drying, it was placed in vacuum plastic bags. After that, chemical composition analyses and fatty acids profile were carried out.

\section{Chemical composition of fresh and freeze-dryingavocado pulp Protein}

The protein content was determined by the nitrogen Dumas method, AOAC 968.06 method, in a LECO TRUSTPEC CN equipment, (LECO Corporation St. Joseph, MI, 2002), $\mathrm{N}_{2}$ freed by pyrolysis and subsequent combustions, is wept by $\mathrm{CO}_{2}$, carrier into nitrometer. $\mathrm{CO}_{2}$ is absorbed in $\mathrm{KOH}$ and volume residual $\mathrm{N}_{2}$ is measured and converted to equivalent protein by numerical factor. $50 \mathrm{mg}$ of sample is placed in a tin 
foil cup for subsequent burning at $850-900{ }^{\circ} \mathrm{C}$ to determine the amount of $\mathrm{N}_{2}$ by nitrometer (28).

\section{Moisture and Ashes}

The determination of moisture and ashes was performed thermogravimetrically with the TGA 701 equipment brand LECO. $1 \mathrm{~g}$ of sample was weighted and kept into porcelain crucible and placed ashes gravimetrical analyzed. The determination of moisture was a $100{ }^{\circ} \mathrm{C}$ by method 930.15 (28) and ashes at $600{ }^{\circ} \mathrm{C}$ by method 942.05 (28).

\section{Crude Fiber}

The crude fiber was obtained through the method of 962.09 of AOAC (1995) Vol II (28). Crude fiber is loss on ignition of dried residue remaining after digestion of sample with $1.25 \% \mathrm{H}_{2} \mathrm{SO}_{4}$ and $1.25 \% \mathrm{NaOH}$ solutions. $2 \mathrm{~g}$ of sample were subjected at acid and alkali digestion during $1 \mathrm{~h}$, the residue was filter with filter paper \#41, after it was dry $2 \mathrm{~h}$ at $130^{\circ} \mathrm{C}$ or overnight, subsequently it was cooled in desiccator at $110^{\circ} \mathrm{C}$ and weighted. Ash $2 \mathrm{~h}$ at $550^{\circ} \mathrm{C}$, cooled in desiccator and weighted.

Total Fat

The total fat was analyzed through the method described by Roese-Gottileb modified (29), NOM-F-512-1988. $2 \mathrm{~g}$ of sample were subjected to extract combined and free acids. Petroleum ether was used to extract the free lipids in Soxhlet apparatus; for acids combined, dilute hydrochloric acid was used to dissolve the lipid-bound proteins.

\section{Fatty acids profile}

The total fat (The Glycerides and phospoholipids) were saponified, and y liberated in presence of $\mathrm{BF}_{3}$ catalyst for further analysis by GC. The fatty acids profile was determined by of gas chromatography-mass spectrometry (GS-MS), through a gas chromatograph with FID detector, brand AGILENT. The chromatographic conditions were as follows: injector temperature $250^{\circ} \mathrm{C}$, detector temperature $25^{\circ} \mathrm{C}$, oven temperature $140-230^{\circ} \mathrm{C}$, Nitrogen was the carrier gas. A standard FAME 37 (C4-C22) was used. The fatty acids were determined through the official method 969.33 and $963.22 \mathrm{~F}$ of the AOAC (30). All of the determinations were performed in triplicate.

\section{RESULTS AND DISCUSSION}

The avocado fruit of the "Hass" variety from the South of Jalisco is made up of $71.39 \%$ pulp, $16 \%$ seed, and $12.61 \%$ skin, which indicates that practically $29 \%$ of the fruit is not edible (data not shown).
Chemical composition and fatty acids profile

With the performance of a joint analysis of the two factors evaluated, freeze-drying (FD) and production conditions (irrigation or rainfed), the results showed significant statistical differences in the chemical composition of the avocado pulp specifically in the content of ashes in the treatments evaluated. On the other hand, in the variable crude fiber, protein and total fat, no significant differences were detected (table 1). The freeze-drying pulp treatment in rainfed conditions presented the largest amount of ashes. In contrast, the treatment with the least amount of ashes was the non-freeze-drying rainfed pulp; while the freeze-drying and non-freeze-drying irrigation pulp were statistically equal, which indicates that freeze-drying in rainfed conditions ( $R C+F D$ ) increased the amount of ashes, but did not do so in irrigation conditions (table 1).

Based on the joint statistical analysis of the two factors evaluated, no significant differences were detected for the variables palmitic and palmitoleic acid. In contrast, for the variables of oleic and linoleic fatty acids, significant differences were detected with $p<0.05$ (table 2 ). For the oleic fatty acid, the treatment of pulp in non-freeze-drying irrigation conditions was the one that presented the greatest amount with 47.48 $\mathrm{g} / 100 \mathrm{~g}$ of this acid and the treatment of non-freeze-drying rainfed pulp was the one that presented the least amount of oleic with $36.59 \mathrm{~g} / 100 \mathrm{~g}$, and the freeze-drying irrigation and rainfed pulp resulted statistically equal. With respect to the linoleic fatty acid, it detected that the greatest percentage of this acid comes from the non-freeze-drying rainfed pulp and the rest of the treatments were the same. The previous reveals that the greatest amount of oleic acid is obtained in non-freeze-drying irrigation pulp and of linoleic in nonfreeze-drying rainfed pulp, which reflects slight increases or decreases when freeze-drying depending on the production condition (table 2).

With regards to the content of palmitic acid registered in the avocado pulps in freeze-drying and non-freeze-drying irrigation and rainfed conditions, these showed values of 12.08 to $14.1 \mathrm{~g} / 100 \mathrm{~g}$, which represent from $17-20 \%$ of the total fat of the fruit. These values are higher than those reported by Ortega (2003) (31) which was $13.76 \%$. Likewise, the values registered of palmitoleic acid 3.99-5.39 g/100g (6-8\%) in the treatments of freeze-drying and non-freeze-drying pulp in irrigation and rainfed conditions are slightly lower than those registered by Ortega 2003 (31) with values of 5.98\%.

The results show that the fatty acids profile of avocado oil is mainly made up of unsaturated fatty acids with $79.7 \%$ and saturated fatty acids in a lower amount (table 2). These

\section{TABLE 1}

Chemical composition of freeze-drying (FD) and non-freeze-drying (NFD) avocado pulp in rainfed $(R C)$ and irrigation conditions (IC).

\begin{tabular}{|c|c|c|c|c|}
\hline Treatment & $\begin{array}{l}\text { Total fat }{ }^{(1)} \\
g / 100 g\end{array}$ & $\begin{array}{l}\text { Protein } \\
\text { g/100g }\end{array}$ & $\begin{array}{l}\text { Ashes } \\
\mathrm{g} / 100 \mathrm{~g}\end{array}$ & $\begin{array}{l}\text { Fiber } \\
\text { g/100g }\end{array}$ \\
\hline (1) Rainfed freeze-drying pulp (RC+FD) & $68.78 \mathrm{a}$ & $6.30 \mathrm{a}$ & $11.24 \mathrm{a}$ & $6.27 \mathrm{a}$ \\
\hline (1) Irrigation freeze-drying pulp (IC+FD) & $71.34 \mathrm{a}$ & $6.25 \mathrm{a}$ & $10.40 \mathrm{ab}$ & $6.25 \mathrm{a}$ \\
\hline (1) Rainfed non-freeze-drying pulp (RC+NFD) & $68.78 \mathrm{a}$ & $5.96 \mathrm{a}$ & $9.40 \mathrm{~b}$ & $6.10 \mathrm{a}$ \\
\hline (1) Irrigation non-freeze-drying pulp (IC+NFD) & $71.39 \mathrm{a}$ & $5.26 \mathrm{a}$ & $10.33 a b$ & $6.23 \mathrm{a}$ \\
\hline
\end{tabular}

\footnotetext{
(1) Expressed in dry basis. Means with the same letter in each column do not mean differences with $p<0.05$
} 
results are similar to those reported by Romero 2012 (32), who mentions that the avocado oil of the "Lorena" variety is made up of $67-70 \%$ unsaturated fatty acids and of $30-33 \%$ saturated fatty acids. Likewise, Campos et al. (2011) (33) reported values in the "Hass" variety of 79-88 \% and 9-15\% of unsaturated and saturated fatty acids, respectively, which reflects the great amount of poly and mono unsaturated fatty acids, which are beneficial for health, as the triglycerides present in the avocado are not fats but oils, as they remain liquids at room temperature (31).

The largest component of the avocado oil was oleic monounsaturated fatty acid with $61 \%$, followed by palmitic saturated fatty acid with $18.8 \%$, linoleic polyunsaturated fatty acid with $11.5 \%$, and palmitoleic monounsaturated fatty acid with 7\% (Table II). Ortega 2003 (31), Campos et al., 2011 (33), and Romero 2012 (32) agree that the main component of the avocado oil is the oleic fatty acid. The values found in this research of 10-15\% of polyunsaturated fats expressed by the linoleic acid in non-freeze-drying and freeze-drying pulp in irrigation and rainfed conditions match those reported by Ortega 2003 (31), who mentions percentages of 8-11\% in the avocado pulp. With regard to saturated fatty acids expressed by the palmitic acid, they showed values of 17 to $20 \%$, which are very similar to the values of $16-22 \%$ registered by Ortega 2003 (31). The values of monounsaturated fat (considering the palmitoleic and oleic acid as monounsaturated) obtained in the treatments $61-73 \%$, are similar to those reported by Ortega 2003 (31) 66-72\%. With regards to the oleic acid, Ortega 2003 (31) and Romero 2012 (32) reported data of 64.87 and $44.4 \%$ in fresh avocado pulp, respectively, values controversial to those detected in freeze-drying and nonfreeze-drying pulp in irrigation and rainfed conditions which range from $53-67 \%$. With regards to the linoleic acid, the values registered in the treatments of freeze-drying and nonfreeze-drying irrigation and rainfed pulp range from 10-15\%, values equal to 14.61 registered by Romero 2012 (32). These slight differenced detected between the results obtained and those of other authors could indicate that the accumulation of lipids is possibly influenced by the type of varieties, the production system, and climate where the fruit is developed, harvest time, and storage of the fruit (34).

\section{Effect of production process on chemical composition and fatty acids profile}

The results show that the irrigation or rainfed production environment statistically affect the amount of total fat, but not the rest of the components of the chemical composition like proteins, ashes and crude fiber. Four percent less total fat is produced in rainfed conditions compared to irrigation (table 3). The diminution in total fat in rainfed conditions is indirectly

\section{TABLE 2}

Palmitic, palmitoleic, oleic, and linoleic acid of freeze-drying (FD) and non-freeze-drying (NFD) avocado pulp in irrigation (IC) and rainfed conditions (RC).

\begin{tabular}{|c|c|c|c|c|c|}
\hline \multirow{3}{*}{$\mathrm{T}$} & \multirow{3}{*}{$\begin{array}{c}\text { Total fat(1) } \\
\text { g/100 g }\end{array}$} & \multirow{3}{*}{$\begin{array}{l}\text { Saturated } \\
\text { Palmitic }{ }^{(1)} \\
\text { g/100 g (\%) }\end{array}$} & \multicolumn{2}{|c|}{ Monounsaturated } & \multirow{3}{*}{$\begin{array}{l}\text { Polyunsaturated } \\
\text { Linoleic }{ }^{(1)} \\
\text { g/100 g (\%) }\end{array}$} \\
\hline & & & Palmitoleic ${ }^{(1)}$ & Oleic ${ }^{(1)}$ & \\
\hline & & & g/100 g (\%) & g/100 g (\%) & \\
\hline $\mathrm{RC}+\mathrm{FD}$ & $68.78 \mathrm{a}$ & $13.26(19) \mathrm{a}$ & $4.98(7) \mathrm{a}$ & $43.24(63) a b$ & 7.29 (11) b \\
\hline$I C+F D$ & $71.34 \mathrm{a}$ & $14.10(20) \mathrm{a}$ & 5.39 (8) a & $44.07(62) a b$ & 7.46 (10) b \\
\hline$R C+N F D$ & $68.78 \mathrm{a}$ & $13.36(19) \mathrm{a}$ & $5.37(8) \mathrm{a}$ & 36.59 (53) b & 10.09 (15) a \\
\hline$I C+N F D$ & $71.39 a$ & $12.08(17) \mathrm{a}$ & $3.99(6) \mathrm{a}$ & $47.48(67) \mathrm{a}$ & 7.53 (10) b \\
\hline Average & 70.07 & $13.2(18)$ & $4.93(7)$ & $42.85(61)$ & 8.09 (11.5) \\
\hline
\end{tabular}

$\mathrm{RC}+\mathrm{FD}=$ Freeze-drying rainfed pulp, IC+FD = Freeze-drying irrigation pulp, $\mathrm{RC}+\mathrm{NFD}=$ Non-freeze-drying rainfed pulp,

$I C+N F D=$ Non-freeze-drying irrigation pulp. ${ }^{(1)}=$ Expressed in dry basis.

$(\%)=$ Expresses the percentage of fatty acid with respect to the total fat. Means with the same letter in each column are not significantly different with $\mathrm{p}<0.05$.

\section{TABLE 3}

Chemical composition of avocado pulp grown in rainfed (RC) and irrigation conditions (IC).

\begin{tabular}{|c|c|c|c|c|c|}
\hline Factor & $\begin{array}{l}\text { Total fat } \\
\mathrm{g} / 100 \mathrm{~g}^{(1)}\end{array}$ & $\begin{array}{l}\text { Protein } \\
\text { g/100 g }\end{array}$ & $\begin{array}{l}\text { Ashes } \\
\mathrm{g} / 100 \mathrm{~g}\end{array}$ & $\begin{array}{l}\text { Fiber } \\
\text { g/100 g }\end{array}$ & $\begin{array}{c}\text { Moisture } \\
\text { g/100 g }\end{array}$ \\
\hline \multicolumn{6}{|c|}{ Expressed in dry basis } \\
\hline IC & $71.37 \mathrm{a}$ & $5.75 \mathrm{a}$ & $10.37 \mathrm{a}$ & $1.8 \mathrm{a}$ & -- \\
\hline RC & $68.78 \mathrm{~b}$ & $6.13 \mathrm{a}$ & $9.90 \mathrm{a}$ & $1.8 \mathrm{a}$ & -- \\
\hline \multicolumn{6}{|c|}{ Expressed in wet basis } \\
\hline IC & 20.06 & 1.49 & 2.90 & 0.50 & 71.89 \\
\hline $\mathrm{RC}$ & 19.85 & 1.52 & 2.71 & 0.52 & 71.13 \\
\hline Average & 19.96 & 1.51 & 2.81 & 0.51 & 71.51 \\
\hline
\end{tabular}

Means with the same letter in each column are not significantly different with $p<0.05$. 
associated to what other authors have reported previously that establishes that with the correct handling of water through an irrigation system the net assimilation of $\mathrm{CO}_{2}$ and therefore the accumulation of photoassimilates increases (35). When considering the chemical composition in wet basis, it shows that the moisture is the main component with 71.51 , followed by lipids with $19.96 \%$, ashes with $2.81 \%$, protein with $1.51 \%$, crude fiber with $0.51 \%$, among others. The results calculated in wet basis are different than those reported by Ariza et al. 2011 (34), who reported $77.3 \%$ moisture, $15.8 \%$ fat, 1.3\% ashes, and $0.4 \%$ fiber for the Hass avocado grown in Mexico. These differences could lie in that in this paper the moisture contents registered are lower than those of Ariza et al. 2011 (34) and therefore show greater percentage of the rest of the components. However, the protein results (1.51) are similar 1.6 value reported by Ariza et al. 2011 (34) and very different a 1.35 value reported by Mooz et al. 2012 (36).

The irrigation and rainfed production conditions did not affect the amount of palmitic, palmitoleic, and linoleic fatty acids, as they had the same statistical results in irrigation and rainfed conditions. In contrast, the oleic fatty acid resulted $5.86 \mathrm{~g} / 100 \mathrm{~g}$ lower in rainfed conditions (table 4), which is directly related to the $4 \%$ decrease of the total fat in rainfed conditions due mainly to the fact that in conditions of proper handling of water (irrigation) an increase in the net assimilation of $\mathrm{CO}_{2}$ has been reported (35).

\section{Effect of freeze-drying on chemical composition} and fatty acids profile

The freeze-drying process did not statistically affect the chemical composition of the avocado pulp in all of the variables evaluated (table 5) resulted statistically equal, thus these results coincide with several authors who have reported that freeze-drying does not affect the nutritional properties of the freeze-drying products (8-10).

The results are consistent with the fact that the state change occurred during the sublimation of water, It minimizes the possibility of loss of macronutrients by drag from interior of the cell; in contrast, other transformation methods, which work with liquid state water, there is a greater probability of damage to the cell structure as is the case of osmotic dehydration $(37,38)$.

The freeze-drying process did not statistically affect the fatty acids profile, except the linoleic acid, which decreased $1.43 \mathrm{~g} / 100 \mathrm{~g}$ in freeze-drying avocado pulp, which represents $16 \%$ less linoleic acid compared to the non-freeze-drying pulp (table 6). This reflects that the freeze-drying process slightly decreases the amount of linoleic acid, which differs from what many authors have set forth who reported that the freeze-drying process does not alter the product's properties $(8,11,12)$, neither affects polyunsaturated fatty acids in meat from different species (39) and in microencapsulated walnut oil (40).

For these reasons, alteration the content of linoleic acid in the fatty acid profile that was found in samples of freeze-drying avocado in this study, are more associated at the storage conditions that the drying process as claimed (40) for the case of unsaturated fatty acids, because the temperature and oxygenation conditions during this stage are detonating potent factors in the autoxidation of fats (41). Additionally, it is shown that the main problem of foods with high content of polyunsaturated fatty acids, particularly long-chain fatty acids, is its high susceptibility to oxidation (42). Therefore, the reduction found only in the proportion of linoleic acid and not in the rest of fatty acid is a result of the higher reactivity of polyunsaturated fatty acids respect to monounsaturated as has been demonstrated in several studies (43).

The final color of the dried pulp was bright green with no signs of enzymatic or non-enzymatic browning. Chlorophyll pigments determines the characteristic green color of the avocado pulp, their thermosensitivity is negative during processing of fruits and vegetables; however, has been found a high stability of those pigments under domestic freezing

TABLE 4

Fatty acids profile of avocado pulp in irrigation (IC) and rainfed conditions (RC).

\begin{tabular}{lccccc}
\hline Factor & $\begin{array}{c}\text { Total fat } \\
\text { g/100g }(\%)\end{array}$ & $\begin{array}{c}\text { Palmitic } \\
\text { g/100g }(\%)\end{array}$ & $\begin{array}{c}\text { Palmitoleic } \\
\text { g/100g } \%)\end{array}$ & $\begin{array}{c}\text { Oleic }^{(1)} \\
g / 100 g(\%)\end{array}$ \\
IC & $71.37 \mathrm{a}$ & $13.09(18) \mathrm{a}$ & $4.69(6.6) \mathrm{a}$ & $45.78(64) \mathrm{a}$ & $7.50(10.5) \mathrm{a}$ \\
RC & $68.78 \mathrm{~b}$ & $13.31(19) \mathrm{a}$ & $5.18(7.5) \mathrm{a}$ & $39.92(58) \mathrm{b}$ & $8.69(12.6) \mathrm{a}$ \\
\hline
\end{tabular}

(1) Expressed in dry basis. (\%) =Expresses the percentage of fatty acid with respect to the total fat.

Means with the same letter in each column are not significantly different with $p<0.05$.

TABLE 5

Chemical composition of freeze-drying (FD) and non-freeze-drying (NFD) avocado pulp.

\begin{tabular}{lcccc}
\hline Factor & $\begin{array}{c}\text { Total fat } \\
\text { g/100 } \mathrm{g}^{(1)}\end{array}$ & $\begin{array}{c}\text { Protein } \\
\text { g/100 g }\end{array}$ & $\begin{array}{c}\text { Ashes } \\
\text { g/100 g }\end{array}$ \\
FD & $70.06 \mathrm{a}$ & $6.27 \mathrm{a}$ & $10.40 \mathrm{a}$ & $1.8 \mathrm{a}$ \\
NFD & $70.09 \mathrm{a}$ & $5.61 \mathrm{a}$ & $9.87 \mathrm{a}$ & $1.8 \mathrm{a}$ \\
\hline
\end{tabular}

${ }^{(1)}=$ Expressed in dry basis. Means with the same letter in each column are not significantly different with $p<0.05$. 
(22). Therefore, it is assumed that the low temperature during processing contribute to the preservation of the color in the dehydrated avocado slices of this study, thereby justifying the use of this temperature range even during storage of the finished product (44), since at cooling or room temperature the rate of chlorophyll degradation increases significantly resulting brown product, especially pheophytin "a" which is derived from the form more thermosensitive of chlorophyll (chlorophyll a) (22).

In this research, the vacuum-packed freeze-drying pulp showed porous and lightweight structure with no evidence of compaction, neither oil exudation was observed during storage, these findings suggests the absence of significant damage to cellular structures (45) caused by excessively large and sharp crystals in the freezing phase $(46,47)$. Oil retention in the dehydrated avocado prevents loss of biological value via by oxidation of mono and polyunsaturated fatty acids by direct exposure to ambient oxygen (48).

In general, the freeze-drying of the fruit only decreased the linoleic acid by $1.43 \mathrm{~g} / 100 \mathrm{~g}$, compared to the non-freezedrying pulp, and the rainfed production system negatively affects the content of total fat and the oleic fatty acid by 4 and $13 \%$ respectively.

\section{CONCLUSIONS}

According to the results obtained we can conclude that freeze-drying avocado pulp experiences slight changes in its nutritional value by presenting a decrease of $1.43 \mathrm{~g} / 100 \mathrm{~g}$ in the linoleic acid (polyunsaturated), thus concluding in, that freeze-drying is a technique with great benefits, despite the possible changes the avocado fruit suffers.

The production conditions affect the nutritional quality of the avocado pulp, reflected in lower amount of total fat by $4 \%$ and oleic acid by $13 \%$ in rainfed conditions.

The fruit is made up of $71.39,16$, and $12.61 \%$ pulp, seed and skin, respectively. The greatest components of the pulp are water and lipids with 71.51 and 19.96\%, followed by ashes, crude fiber, and protein with $2.81,0.51$, and $1.51 \%$, respectively.

The fatty acids profile of the avocado is distributed in $61,18.8,11.6$ and $7 \%$ of oleic (monounsaturated), palmitic (saturated), linoleic (polyunsaturated), and palmitoleic (monounsaturated) fatty acids respectively.

\section{RESUMEN}

La tecnología de liofilización es el mejor proceso de deshidratación para mantener mayor vida de anaquel y conservar las propiedades nutricionales y sensoriales de la pulpa del aguacate. El objetivo de este estudio fue deter- minar si el liofilizado y condición de producción tienen un efecto sobre la calidad nutrimental de la pulpa de aguacate cultivado en huertas de riego y temporal. Se aplicaron 4 tratamientos: frutos de temporal no liofilizado, frutos de riego no liofilizado, frutos liofilizados de temporal y frutos liofilizados de riego. Los resultados muestran que el fruto está compuesto por 71.39, 16 y 12.6\% de pulpa, hueso y cáscara respectivamente. La pulpa está compuesta por 71.51, $19.96,2.81,0.51$ y $1.5 \%$ de humedad, lípidos, cenizas, fibra cruda y proteína, respectivamente. El aceite del aguacate está constituido de 61. 18.8, 11.6 y 7\% de ácidos grasos oleico, palmítico, linoléico y palmitoleico, respectivamente. El liofilizado disminuyó $1.43 \mathrm{~g} / 100 \mathrm{~g}$ de ácido linoléico. Bajo condiciones de temporal se produce 4 y $13 \%$ menos grasa total y ácido graso oleico que en condiciones de riego. Se concluye que la pulpa del aguacate liofilizada presenta ligeros cambios en su calidad nutrimental.Palabras claves: ácidos grasos; liofilizado; riego; temporal.

\section{BIBLIOGRAFÍA}

1. Téliz D, Marroquín P. Importancia histórica y socioeconómica del aguacate. in Téliz, D. \& Mora, A. (Eds.), El aguacate y su manejo integrado, 1-28. Ediciones Mundiprensa. México 2008.

2. SIAP (Servicio de Información Agroalimentaria y Pesquera) 2011. Disponible en http://www.siap.gob. $m x /$ index.php?option=com_content\&view=article \&id=10\&/t emid $=2012$

3. OEIDRUS Exportaciones de aguacate. Disponible en: http:// www.oeidrus-jalisco.gob. $\mathrm{mx} /$ mercados/exportaciones/ aguacate/, 2013.

4. SAGARPA. Hay avances en el proceso de exportación de aguacate de Jalisco a Estados Unidos. Boletín de Prensa. 2011 in: http://www.sagarpa.gob.mx/Delegaciones/ jalisco/boletines/2011/julio/Documents/B0552011.pdf

5. Oleata, J. Industrialización del aguacate: estado actual perspectivas futuras. Proceedings V World Avocado Congress (España), 2003, p 749-54.

6. Ortiz A, Mora R, Santiago T, Dorantes L. Obtención de una pasta de aguacate mediante tratamiento térmico. $V$ World Avocado Congress (España), 2003, p 761-8.

7. Gómez H, Parra R, De Santos A, Fréderic R. Modelo computacional para la liofilización de alimentos de geometría finita. revista Digital Científica y Tecnológica e-Gnosis. 2003; 1(11): 1-27.

8. Grajales-Agudelo L, Cardona-Perdomo W, Orrego-Alzate C. Liofilización de carambola (Averrhoa carambola L.) osmodeshidratada. Ingeniería y Competitividad. 2006; 7(2): 19-26.

\section{TABLE 6}

Fatty acids profile freeze-drying (FD) and non-freeze-drying (NFD) avocado pulp.

\begin{tabular}{|c|c|c|c|c|c|}
\hline Factor & $\begin{array}{c}\text { Total fat }{ }^{(1)} \\
\mathrm{g} / 100 \mathrm{~g}\end{array}$ & $\begin{array}{l}\text { Saturated } \\
\text { Palmitic } \\
\text { g/100 g (\%) }\end{array}$ & $\begin{array}{l}\text { Monounsaturated } \\
\text { Palmitoleic }{ }^{(1)} \\
\text { g/100 g (\%) }\end{array}$ & $\begin{array}{c}\text { Monounsaturated } \\
\text { Oleic }{ }^{(1)} \\
\text { g/100 g (\%) }\end{array}$ & $\begin{array}{l}\text { Polyunsaturated } \\
\text { Linoleic } \\
\text { g/100 g ( } \%)\end{array}$ \\
\hline FD & $70.06 \mathrm{a}$ & 13.68 (19.5) a & $5.19(7.4) \mathrm{a}$ & $43.66(62) \mathrm{a}$ & $7.38(10.5) b$ \\
\hline NFD & $70.09 \mathrm{a}$ & $12.72(18.1) \mathrm{a}$ & $4.68(6.7) \mathrm{a}$ & $42.03(60) \mathrm{a}$ & $8.81(12.6) \mathrm{a}$ \\
\hline
\end{tabular}


9. Ciurzyńska A, Lenart A. Freeze-Drying - Application in Food Processing and Biotechnology, A Review Pol. J Food Nutr Sci. 2011; 61(3):165-71.

10. Ivančević S, Mitrovic D, Brkić M, Cvijanovic D. Specifities of fruit freeze drying and product prices. Economics Agricul. 2012; 59(3): 461-71.

11. Amrani $M$, Brigui J. Impacto del proceso de liofilización en la calidad de las fresas. rev Ingen Invest. 2007; 27(2): 51-5.

12. Veras $A$, Béttega $R$, Freire B, Barrozo M, Freire J. Drying kinetics, structural characteristics and vitamin $c$ retention of dedo-de-moça pepper (Capsicum baccatum) during convective and freeze drying. Braz J of Chem Eng. 2012; 29(4): 741-50.

13. Arriola G, García H, Guatemala M, Ningaray A, Gonzáles $R$, Ruíz G. Comportamiento del aguacate Hass liofilizado durante la operación de rehidratación. Rev Mex Ing Quím. 2006; 5(1): 51-6.

14. Sanginés L. Aguacates en alimentación humana y animal. rev Comput Produc Porcina. 2008; 15(3): 211-5.

15. Rodríguez-Campos J, Escalona-Buendía H B, Orozco-Avila I, Lugo- Cervantes E, Jaramillo-Flores M E. Dynamics of volatile and non-volatile compounds in cocoa (Theobroma cacao L.) during fermentation and drying processes using principal components analysis. Food Res Internat. 2011; 44: 250-8.

16. Li X, Feng T, Zhou F, Zhou S, Liu Y, Li W, Ye R, Yang Y. Effects of drying methods on the tasty compounds of Pleurotus eryngii. Food Chem. 2015; 166: 358-64.

17. Pei $F$, Shi $Y$, Gao $X, W u$ F, Mugambi $M A$, Yang $W$, Zhao $L$, An $X$, Xin Z, Yang $F$, Hua $Q$. Changes in non-volatile taste components of button mushroom (Agaricus bisporus) during different stages of freeze drying and freeze drying combined with microwave vacuum drying. Food Chem. 2014; 165: 547-54.

18. Hua Z, Zhen-Yu W, Xin Y, Hai-Tian Z, Ying-Chun, Z, Ai-Jun $D$, Jing $J J W$. Determination of free amino acids and 18 elements in freeze-dried strawberry and blueberry fruit using an Amino Acid Analyzer and ICP-MS with micro-wave digestion. Food Chem. 2014; 147: 189-94.

19. Chan $E W C$, Lim $Y Y$, Wong $S K$, Lim $K K$, Tan S P, Lianto $F S$. Yong $M Y$. Effects of different drying methods on the antioxidant properties of leaves and tea of ginger species. Food Chem. 2009; 113: 166-72.

20. Pinela J, Barros L, Carvalho A M, Ferreira I C F R. Influence of the drying method in the antioxidant potential of four shrubby flowering plants from the tribe Genisteae (Fabaceae). Food Chemical Toxicol. 2011; 49: 2983-9.

21. García-Salas $P$, Gómez-Caravaca $A$ M, Arráez-Román D, Segura-Carretero A, Guerra-Hernández E, García-Villanova $B$, Fernández-Gutiérrez A. Influence of technological processes on phenolic compounds, organic acids, furanic derivatives, and antioxidant activity of whole-lemon powder. Food Chem. 2013; 141: 869-78.

22. Steele $R J$ J, Johnson $R$ L. New strategies for kiwifruit processing. International J Food Sci Technol. 1995; 30:13-21.

23. Ghasemi A P, Oraie M, Pouriamehr M, Solaymani B E. Effects of drying methods on qualitative and quantitative of the essential oil of Bakhtiari savory (Satureja bachtiarica Bunge). Industrial Crops Products. 2013a; 46: 324-7.

24. Ghasemi A P, Mahdad E, Craker L. Effects of drying methods on qualitative and quantitative properties of essential oil of two basil landraces. Food Chem. 2013b; 141: 2440-9.

25. Calvo P, Castaño A L, Hernández M T, González-Gómez. Effects of microcapsule constitution on the quality of mi- croencapsulated walnut oil. European J Lipid Sci Technol. 2011; 113: 1273-80.

26. Schwartz M, OlaetaJ A, Undurraga P, Sepúlveda M Obtención y almacenamiento de palta (aguacate) en polvo in: Proceedings VI World Avocado Congress. Viña del Mar, Chile. 12-16 Nov, 2007. ISBN No 978-956-17-0413-8.

27. (18). Statistical Analysis System (SAS) for Windows V 9.0

28. Association of Official Analytical Chemists. Official methods of analysis of the AOAC (1995). Crude protein: chapter4, p.5-7, moisture: chapter 4, p. 2 and ashes: chapter 4 p. 4.

29. Norma Oficial Mexicana NOM-086-SSA-1994, Bienes y servicios. Alimentos y bebidas no alcohólicas con modificaciones en su composición. Especificaciones nutrimentales. http://dof.gob.mx/nota_detalle.php?codigo $=5172062 \& f$ echa=22/12/2010

30. (17). Association of Official Analytical Chemists. Official methods of analysis of the AOAC (1990). Métodos oficiales 969,33 y 963,22 15th Edición Vol II.

31. Ortega T. Valor Nutrimental de la pulpa fresca de aguacate Hass. Proceeding V World Avocado Congress (España), 2003; $p$ 741-8.

32. Romero S. 2012. Comportamiento fisiológico del aguacate (Persea americana mill.) Variedad Lorena en la zona de Mariquita, Tolima. Tesis de Maestría. Universidad Nacional de Colombia, Facultad de Agronomía, Escuela de Posgrados, Bogotá, Colombia. http://www.bdigital.unal. edu.co/6342/1/790700.2012.pdf

33. Campos $R$, Santacruz, U, Flórez $M$, Rivera $G$, RodríguezPérez J. Dinámica de la acumulación de ácidos grasos en aguacate (Persea americana Mill.) selección 'Méndez'. VII World Avocado Congress (Australia), 2011; 1-8.

34. Ariza O, López F, Coyotl J, Ramos M, Díaz J, Martínez A. Efecto de diferentes métodos de extracción sobre el perfil de ácidos grasos en el aceite de aguacate (Persea americana Mill. var. Hass). Rev Ven Cienc Tecnol Aliment. 2011; 2(2): 263-76.

35. Silber A, Israeli Y, Levi M, Keinan A, Shapira O, Chudi G, Golan A, Noy M, Levkovitch I, Assouline S. Response of 'Hass' avocado to temporal stresses: role of irrigation management and root constraint. VII World Avocado Congress. (Australia), 2011; 1-10.

36. Mooz D, Gaino M, Shimano H, Amancio D, Spoto F. Physi$\mathrm{cal}$ and chemical characterization of the pulp of different varieties of avocado targeting oil extraction potential. Ciênc Tecnol Aliment Campinas. 2012; 32(2):274-80.

37. Abraão, S A, Lemos $M A$, Vilela A, Sousa $M J$, Nunes $F M$. Influence of osmotic dehydration process parameters on the quality of candied pumpkins. Food Bioproducts Processing. 2013; 91: 481-94.

38. Silva SK, Fernández M A, Mauro A M. Effect of calcium on the osmotic dehydration kinetics and quality of pineapple. J Food Engineering. 2014; 134: 37-44.

39. Lee M R F, Tweed J KS, Kim EJ, Scollan N D. Beef, chicken and lamb fatty acid analysis - a simplified direct bimethylation. Meat Science. 2012; 92: 863-66.

40. Calvo P, Castaño A L, Hernández M T, González-Gómez $D$. Effects of microcapsule constitution on the quality of microencapsulated walnut oil. European J Lipid Sci Technol. 2011; 113: 1273-80.

41. Roman $O$, Heyd B, Broyart B, Castillo R, Maillard M N. Oxidative reactivity of unsaturated fatty acids from sunflower, high oleic sunflower and rapeseed oils subjected to heat treatment, under controlled conditions. LWT - Food Sci Technol. 2013; 52: 49-59. 
42. Martin-Polvillo M, Marquez-Ruiz G, Dobarganes M C. Oxidative stability of sunflower oils differing in unsaturation degree during long-term storage at room temperature. J Am Oil Chem Soc. 2004; 81(6): 577-83.

43. Parker T D, Adams D A, Zhou K, Harris M, Yu L. Fatty acid composition and oxidative stability of cold-pressed edible seed oils. J Food Sci. 2003; 68(4): 1240-43.

44. Ramírez-Anaya J P. Estudio fisicoquímico de la tuna (Opuntia ficus-indica) para su aprovechamiento agroindustrial. Tesis de Maestría en Procesos Biotecnológicos. Universidad de Guadalajara, México. 2006. p 297.

45. Fuchigami M, Kato N, Teramoto A. High-pressure-Freezing effects on textural quality of carrots. J Food Sci. 1997;
64(4): 804-8.

46. Canet $E$, Alvarez M D. Congelación de los alimentos vegetales. Aplicación del frío a los alimentos. Lamúa S. M (Ed), Mundi Prensa. 2000. España, p 201-58.

47. Allan-Wojtas $P$, Goff $H$ D, Stark $R$, Carbyn S. The effect of freezing method and frozen storage conditions on the microstructure of wild blueberries as observed by coldstage scanning electron microscopy. Scanning. 1999; 21(5): 334-47.

48. Meyer $M D$, Terry $L$ A. Development of a rapid method for the sequential extraction and subsequent quantification of fatty acids and sugars from avocado mesocarp tissue. J Agric Food Chem. 2008; 56(16): 7439-45. 